\title{
Design for Songket Weaving in Malay Cottage Industry
}

\section{Min Zhang}

Lancaster University

Lancaster, LA1 4WA, UK

m.zhang18@lancaster.ac.uk

\section{Corina Sas}

Lancaster University

Lancaster, LA1 4WA, UK

c.cas@lancaster.ac.uk

Masitah Ahmad

Universiti Teknologi MARA

42300 Shah Alam, Selangor,

Malaysia

masitah@uitm.edu.my

Paste the appropriate copyright statement here. ACM now supports three different copyright statements: - ACM copyright: ACM holds the copyright on the work. This is the historical
approach.

License: The author(s) retain copyright, but ACM receives an exclusive

publication license.

Open Access: The author(s) wish to pay for the work to be open access. The additional fee must be paid to ACM.

This text field is large enough to hold the appropriate release statement assuming it is single spaced in a sans-serif 7 point font.

Every submission will be assigned their own unique DOI string to be included here.

\begin{abstract}
Songket is a traditional cultural heritage and national identity of Malaysia. Yet the hand-weaving practices are increasingly endangered. We know little about the current challenges faced by rural songket weavers. This paper reports on interviews with 12 home-based weavers from four Malay villages. We recognized two key actors in songket supply and demand chain: weaver and middleman, and outlined the motivations and challenges of three different types of weavers, alongside the multiple roles played by the middleman. We concluded with three design implications supporting songket cultural heritage preservation and weavers' economic empowerment.
\end{abstract}

\section{Author Keywords}

Cultural Heritage Preservation; ICTD; Infrastructure; Handicraft.

\section{ACM Classification Keywords}

H.5.m [Information interfaces and presentation (e.g., $\mathrm{HCl}$ )]: Miscellaneous.

\section{Introduction}

Songket weaving is a Southeast Asian craft [14] practised by women for more than two centuries. The traditional practice of songket weaving, a hallmark of Malay cultural heritage, has been passed down through oral tradition in fa- 


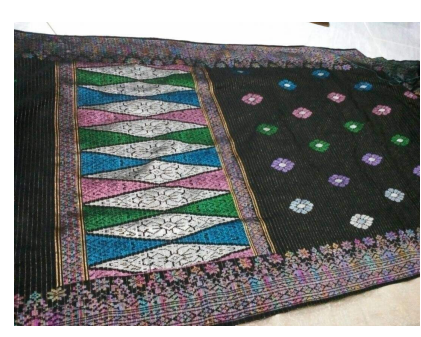

Figure 1: A songket fabric.

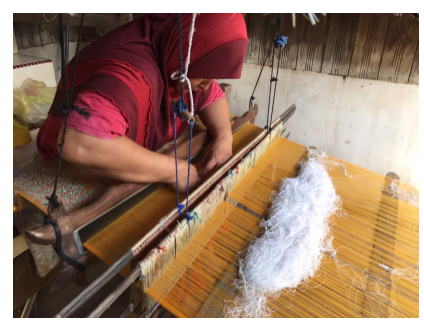

Figure 2: A home-based weaver is weaving songket on a handloom.

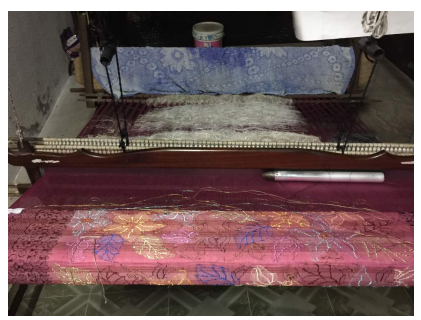

Figure 3: Partially completed songket on a handloom. milial context, and has provided the main source of income to many women in rural areas [9]. As most Malay people continue to wear clothes made of songket fabric (Figure 1. Note: all photos in Figure 1-5 are credited by third author) during special occasions, such as wedding ceremony, religious festival, social and national functions [9, 14], and the fabric is under much demand. However, the traditional songket weaving skills are increasingly endangered due to rapid economic development of factory-based weaving. The industrial textiles utilize jacquard loom with punch card [2], for mass production. The intense manual labor of homebased songket handweaving on handlooms (see Figure 2 - 4), and its limited income is providing less incentive for the younger generations to inherit these skills [9]. A few homegrown songket weavers have also started to adopt computer-aided technology for songket design, such as Microsoft Paint [14].

The limited scholarly work exploring this weaving practice has identified the critical role of middleman in songket production hierarchy more than two decades ago [8]. However, we know little about the current challenges of Malay songket weavers in rural areas. This paper reports interviews with 12 women to identify such challenges and design opportunities for supporting the preservation of cultural heritage and the improvement of weavers' income generation.

\section{Related Work}

This paper draws from $\mathrm{HCl}$ work on the digital craft [13], cultural heritage, and $\mathrm{HCl}$ in developing context (HCID) [6]. A growing body of work has examined the digital innovation within traditional handicraft. For example, Rosner and Ryokai [11] proposes a system allowing users to record messages during the knitting process for sharing stories and memories; same as personal items such as jewelry [1] and photo album [15]. Golsteijn and colleagues [3] proposed the concept of hybrid crafting which integrates the physical craft practice with digital components.

Another strand of $\mathrm{HCl}$ work has explored digital technology to access and store tangible and intangible cultural heritage [4], particularly in interactive museums [10], for richer user engagement. Other researchers argued for increasing cultural identity and value $[4,16]$. For example, Tan and Blevis prototyped a system to assist villagers to build pride in cultural craft by integrating a map with QR narratives of craft [16].

Much $\mathrm{HCl}$ work in the developing contexts has focused on culture preservation [16], local infrastructure [7], or woman economic empowerment [5] in rural areas. A recent study focused on the emerging infrastructure of an online clothing selling shop in rural Cambodia integrating Facebook, mobile phones, paper invoices, maps, and a delivery system [7].

We also acknowledge the importance of understanding the existing sociotechnical context and infrastructure that could help us design for more fair and empowering songket weaving practices and marketplaces in rural Malaysia. Although the Malay government has taken active actions in revitalizing this cultural heritage [8], through the programs of training and support, the majority of home-based weavers have limited benefits, while older and traditional artisans are usually marginalized [8]. One such initiative is the 1 Nita Portal [5], providing an online platform for women entrepreneurs to grow their businesses.

\section{Methods}

The study consisted of contextual semi-structured interviews with 12 weavers in their homes in rural Malaysia. Participants were recruited from four villages in Terengganu where finer workmanship and authentic songket ex- 


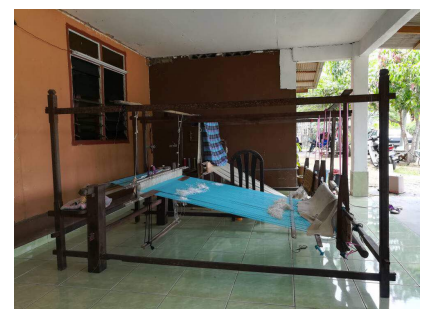

Figure 4: A bulky songket handloom is usually placed at weaver's home.

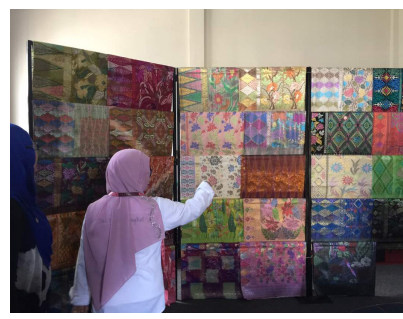

Figure 5: A entrepreneurial weaver shows her songket fabrics at her home which is also her workshop.

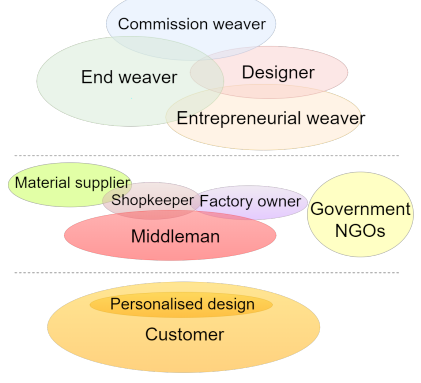

Figure 6: The stakeholders on Malaysian Songket market. ist [9], and with help from a local NGO championing the wellbeing of women and their economic roles. We asked the questions about the motivations and the process of songket production, material supplying and songket distribution, songket authentication and what benefits they get from songket weaving.

All participants are women, between 34 and 80 years old, and educated at middle or high school. They are housewives with no additional income other than from songket weaving at home on handloom (Figure 4). The interviews lasted around two hours in Malay and were audio-recorded, and fully transcribed and translated into English. Participants were rewarded RM20 (Malaysian Ringgit) for their time.

\section{Findings \& Discussions}

Two key actors in songket supply and demand chain are recognized from interviews: weaver and middleman. Findings indicate the motivations and challenges of weavers, different types of weavers and their activities, as well as middlemen's roles.

\section{Motivations for Songket Weaving}

It is indicated that weavers appreciate the financial benefits of songket weaving allowing them to improve the quality of life or to support their children's education.

\section{Types of Weavers}

A novel outcome is the different types of weavers: end weaver (9), commission weaver (2), and entrepreneurial weaver (1) (Figure 6). Findings suggest that most homebased end weavers have no end customers, relying exclusively on the middleman for songket orders. End weavers just sell their low-cost labor to middlemen and get paid on a piece basis after completion. Thus, end weavers can earn more by increasing the efficiency and volume of their work.
A few end weavers (2) have had occasional direct customers, usually friends or people recommended by family and friends: "Once in a while, there are people who come to my house and asked to buy songket directly from me. But it does not always happen" [P6]. However, such orders are placed once or twice per year prior to special occasions such as Hari Raya celebration [P12] or wedding ceremonies. As weavers are getting old, they only work for the middleman to avoid the additional stress of reaching customers.

The commission weavers work on commissions taking bulk order from the middleman and allocating it to her network of end weavers, usually family and friends within the village. Interestingly, this type of weavers also has their own end customers. Besides receiving customers' orders in the same way of the end weavers, the commission weavers also initiate "marketing product to customers in city or town and local people" [P8].

The entrepreneurial weaver identified in our findings employs 20 weavers working in a workshop equipped with handlooms. She bears the responsibility of buying materials in bulk usually from China. As such materials are expensive, the avenue of shared purchases is emerging: "for the special materials like the expensive gold threads, my friend [entrepreneurial weaver] buys in bulk. She asked me to join and share the capital so we can buy in bigger bulk, but I cannot afford. A spool of thread costs RM100, it is expensive" [P12]. Entrepreneurial weavers also need to find customers and to market handmade songkets, usually through word-of-mouth and digital technology: "I can use the website or social media to market products now" [P9]. This indicates the willingness to adopt appropriate novel technologies for economic empowerment. 
Findings also indicate the motivation for entrepreneurial initiatives, and the progression of such effort from end weaver to commission weaver and ultimately entrepreneurial weaver.

\section{Multiple Functions of Middleman}

Another important outcome is the different functions played by the middleman. While previous work has shown the emergence of middleman in songket production and trade from the mid-1980s [8], our findings show that they continue to hold a central role in bridging weavers and customers on songket market (Figure 6). In particular, a novel outcome is that the middlemen play a range of critical roles both for weavers, i.e., maintaining a network of weavers, buying materials in bulk and delivering them to weavers, collecting songket fabrics from weavers' homes and paying them, monitoring the quality of weavers' work and marketing songket; as well as for end customers, i.e., finding and building customer base, negotiating songket design and price with customers, delivering songket and receiving payment, and providing customer service.

\section{Weaver's Challenges}

An important challenge faced mostly by end weavers is accessing customers. Indeed, home-based weavers found it is hard to get direct customers, as customers usually tend to know the seller or middleman rather than maker of songket: "normally people will go straight to famous sellers who sell at a very high price but people still buy" [P12]. Getting customers requires communicating with the world outside the village, either physically or digitally. However, many home-based weavers have limited mobility: "I cannot work far from home because I am a single mother and have to manage my kids at the same time" [P3]P.

Another challenge is the power asymmetry between middleman and weaver. The vulnerability of home-based weavers as largely unrecognized and low-paid workers has also been previously suggested [8]: "now weavers get a very small amount of money. The selling price is RM1000-2000 per piece, which takes 30-45 days to finish at a normal speed. After deducting the cost of materials, I get RM100 (24.5 US dollars) only. So my profit is very small" [P12].

This situation may be because weavers have no other choice: the middleman usually has the monopoly of delivering songket orders to a village, and the weavers find it difficult to overcome the mobility challenge related to household chores and family care. In addition, end weavers also face financial challenges as they cannot afford to buy expensive threads of gold or silk in bulk. Thus they depend heavily on the middlemen for providing these materials in credit.

Another challenge regards the customization of songket design. Although the traditional songket design is often accepted as such, an emerging trend indicates customer's interest in personalizing it with contemporary patterns which come with a higher songket price [P12]. Findings indicate that songket design is customized with limited input from end weavers, with the middleman negotiating design directly with customers and passing customer's requirements to the weaver. Such requirements usually include the specific choice of colors and patterns. Despite the higher income from customized songket, few weavers engage in the design of songket patterns, because they lack the skills needed for contemporary designs.

Finally, the fourth identified challenge relates to the protection of the authenticity of songket design. Songket weavers develop the tacit knowledge of traditional songket patterns as confirmed by previous findings on geography-based pattern uniqueness [8]: "all weavers know the design by memorizing effortlessly because we do it everyday" [P5], and "every piece made in this village is surely authentic" [P4]. 
While end weavers have no concern with the issue of design protection, those who do engage in novel design such as the entrepreneurial weaver have an awareness of this issue: "after the design paper is used, it must be destroyed to preserve its uniqueness" [P9]. These findings suggest that although authenticity is prized, weavers lack tools to document it and ultimately use it to better market their songket.

\section{Implications for Design}

These findings led to three design implications for preserving songket cultural heritage by strengthening weavers' economic empowerment. These include novel tools supporting weavers' online presence and access to songket supply and demand chain, new tools for songket authentication, together with an awareness of the disruptive impact of these technologies on middleman whose multiple roles need to be either physically or digitally provided.

Accessible Tools for Weavers' Online Presence and Access to Songket Supply and Demand Chain

Songket weavers and end customers are often invisible to each other. End weavers only play the role of producer, with limited awareness of the supply and distribution chain. Although weavers have initiatives to enlarge their business, they have mobility constraints having to work from home. This opens the design opportunities for novel tools requiring limited digital literacy [12] for empowering weavers through online presence to showcase their craft for reaching new customers. Such tools could also support weavers' access to supply chain so that they can collaboratively purchase affordable materials in bulk promoting a co-operative mode for community-based enterprise in this developing context.

\section{Songket Authentication Tool}

Despite the increasing adoption of songket mass-production, the traditional manual labor of songket weaving has its own market and growing demand, particularly for customized contemporary design. One can think of novel tools such as block-chain technology smoothly integrated into weaving practices to capture the authenticity of handwoven songket, in terms of material qualities and sources, and the genuine hand-weaving process.

\section{Digital Middleman Platform}

Findings suggest that the middleman plays multiple roles on songket market and benefits from the considerable share of the selling price. However, if we design technologies to support wavers circumventing the power of middleman for their own economic empowerment, such technologies should support and arguably extend the range of functions currently provided by the middleman, including for example, the co-design function between customers and weavers. Thus, the disruptive effect of such technology should be also considered alongside with support from the government. This case also opens $\mathrm{HCl}$ attention to communitybased research.

\section{Conclusions}

This fieldwork explores the practice of home-based songket weaving in rural Malaysia. We report on interviews with 12 weavers from four villages in Terengganu. Findings indicate different types of weavers and their motivations and challenges, together with the multiple roles played by the middleman. We proposed three design implications for supporting cultural heritage preservation and rural women's economic empowerment.

\section{Acknowledgement}

This work is supported by Digital Threads: Towards personalised craft production in Malay cottage industries, funded by AHRC UK (Grant No. AH/P014186/1). 


\section{REFERENCES}

1. Cerys Alonso. 2015. The Narrative of Craft: Digital Capabilities within Traditional Stories. In 2015 Internet Technologies and Applications. 520-523.

2. Ylva Fernaeus, Martin Jonsson, and Jakob Tholander. 2012. Revisiting the Jacquard Loom: Threads of History and Current Patterns in HCI. In Proc. of CHI'12. 1593-1602.

3. Connie Golsteijn, Elise Van Den Hoven, David Frohlich, and Abigail Sellen. 2014. Hybrid Crafting: Towards an Integrated Practice of Crafting with Physical and Digital Components. Personal and Ubiquitous Computing 18 , 3 (2014), 593-611.

4. Mónica Isabel González, Emilio Sánchez, and Edgar de los Santos. 2011. ViTu: A System to Help the Mexican People to Preserve and Celebrate their Culture. In CHI'11 EA. 971-976.

5. Fuzirah Hashim, Norizan Abdul Razak, and Zaini Amir. 2011. Empowering Rural Women Entrepreneurs with ICT Skills: An Impact Study of 1 nita Project in Malaysia. Procedia - Social and Behavioral Sciences 15 (2011), 3779-3783.

6. Melissa R M.R. Ho, Thomas N T.N. Smyth, Matthew Kam, and Andy Dearden. 2009. Human-Computer Interaction for Development: The Past, Present, and Future. Information Technologies and International Development 5, 4 (2009), 1-18.

7. Margaret Jack, Jay Chen, and Steven J Jackson. 2017 Infrastructure as Creative Action: Online Buying, Selling, and Delivery in Phnom Penh. In Proc. of CHI'17. 6511-6522.
8. Maznah Mohamad. 1996. The Malay Handloom Weavers: A Study of the Rise and Decline of Traditional Manufacture. Institute of Southeast Asian Studies.

9. June Ngo Siok Kheng. 2011. Revitalising the Craft of Songket Weaving through Innovation in Malaysia. Technical Report. Universiti Malaysia Sarawak.

10. Daniela Petrelli, Luigina Ciolfi, Dick van Dijk, Eva Hornecker, Elena Not, and Albrecht Schmidt. 2013. Integrating Material and Digital: A New Way for Cultural Heritage. Interactions 20, 4 (July 2013), 58-63.

11. Daniela Rosner and Kimiko Ryokai. 2008. Weaving Memories into Handcrafted Artifacts with Spyn. In $\mathrm{CHI}$ '08 EA. 2331-2336.

12. Corina Sas and Carman Neustaedter. 2017. Exploring DIY Practices of Complex Home Technologies. ACM Trans. on Computer-Human Interaction 24, 2 (April 2017), 16:1-16:29.

13. Corina Sas, Karen Wisbach, and Alina Coman. 2017. Craft-based Exploration of Sense of Self. In CHI'17 EA. 2891-2899.

14. Suzanne Stankard. 2010. Textile Praxis: The Case for Malaysian Hand-Woven Songket. Ph.D. Dissertation. The Royal College of Art.

15. Molly M. Stevens, Gregory D. Abowd, Khai N. Truong, and Florian Vollmer. 2003. Getting into the Living Memory Box: Family Archives \& Holistic Design. Personal and Ubiquitous Computing 7, 3-4 (2003), 210-216.

16. Haodan Tan and Eli Blevis. In press 2017. Preserving Chinese Craft Heritage by Forging Rural-Urban Connections. In Proc. of International Association of Societies of Design Research. 